the Ministry of Labour and of other organizations ; also that another organization is contemplating the provision of facilities which may offer arrangements for periodical meetings of allied scientific workers.

\section{Carrots for Domestic Animals}

WAR conditions have established the merits of carrots as an ingredient of the human dietary : that they are no less excellent as a food for farm animals, is shown in a recent article by Mr. H. E. Woodman, of the School of Agriculture, Cambridge (J. Min. Agric., 48 , No. 3, 185; 1941). Indeed, all kinds of stock are fond of carrots, and although their importance in animal feeding is overshadowed by that of the other root crops - swedes, mangolds and turnips-. this is not due to any inferiority in feeding quality, but rather to price considerations and to the fact that when the human requirements in Great Britain have been met, the supply of carrots left over for animals has usually been quite small. This year it seems there will be a large surplus. On the basis of starch equivalents, $80 \mathrm{lb}$. of carrots should be able, on an average, to replace $100 \mathrm{lb}$. of mangolds, or $90 \mathrm{lb}$. of swedes. With the more watery turnips, however, two parts by weight may be replaced by one part of carrots. Carrots are not so rich as swedes in vitamin $\mathrm{C}$, the anti-scurvy factor, but are distinguished from all other roots by their high content of carotene. Since this yellow pigment is convertible into vitamin $\mathbf{A}$ in the body of the animal, it follows that carrots are a good source of this important health factor.

Raw carrots have always been a favourite food for horses. The allowance should not exceed $20 \mathrm{lb}$. per head per day, but smaller amounts may be fed with benefit to condition. They should be used in partial replacement of oats, $7 \mathrm{lb}$. of carrots being equal to $1 \mathrm{lb}$. of the cereal. Dairy cows may receive up to $40 \mathrm{lb}$. of sliced carrots per head per day and fattening bullocks up to $60 \mathrm{lb}$. The carotene in the carrots enriches the colour of winter milk and improves its content of vitamin $\mathbf{A}$, and for this reason, carrots are specially valuable when the dairy ration contains neither kale nor silage. They may be used to replace dried sugarbeet pulp $(7 \mathrm{lb}$. of carrots $=1 \mathrm{lb}$. of dried beet pulp) or cereals $(8 \mathrm{lb}$. of carrots $=1 \mathrm{lb}$. of crushed barley). Pigs may also be given carrots with advantage to health and condition; and cereal meal, up to one fifth of the total ration, may be replaced by this succulent food, of which $8 \mathrm{lb}$. should be fed for every $\mathrm{lb}$. of cereal meal replaced. The carrots form a useful source of vitamin $A$ for pigs that are kept entirely indoors. Some authorities recommend cooking or steaming them for pigs, but the full beneficial effect is only obtained when they are fed raw. Grated or shredded carrots, when mixed with the meal ration, provide a palatable and healthpromoting feed. Carrots form a useful supplement to the growing and laying mashes of poultry during winter, and their vitamin A potency is particularly beneficial in these cases. They are best fed raw. Grated or shredded carrots may replace cereals up to one fifth of the total mash, 8 parts by weight being used to replace 1 part of cereal.

\section{Carnegie Corporation of New York}

IN the report of the president of the Carnegie Corporation of New York, covering the year ended September 30, 1941, Mr. Frederick P. Keppel, who retired from the presidency on November 18, states that of grants totalling 2,706,834 dollars made during the year, 500,000 dollars were allocated for matters relating directly to the national emergency. Special stress is laid upon the importance of timing in enterprises involving effective co-operation between public and private agencies, public offices, and private citizens or groups. Besides contributions to the National Academy of Sciences totalling 100,000 dollars, emergency grants were made to the Institute of Public Administration for special studies undertaken at the request of Government agencies, to Harvard University for training supply officers, to the National Bureau of Economic Research and the Institute of Pacific Relations, as well as to other agencies. Of other grants, 398,511 dollars was allotted for library interests, including support of the Journal of Documentary Reproduction, 566,930 dollars for adult education and 906,956 dollars for research and studies. The Committee on Scientific Aids to Learning has steadily proceeded with its work in the fields selected for intensive study, namely, the problems of microphotography, including visual fatigue, and the development of the best visual and auditory equipment for classroom use. From the special fund set aside by Mr. Carnegie for the Dominions and Colonies, 70,000 dollars was allotted for library and educational services in Trinidad and the Windward and Leeward Islands, 30,000 dollars for the research activities of the International Labour Office at McGill University, 14,800 dollars to the Canadian Research Council in the Social Services and 7,500 dollars to the Royal Institute of International Affairs for a study of the internal economy and external relations of Newfoundland; a further grant has also been made to the Carnegie Endowment for International Peace.

Mr. Keppel's report includes a review of developments and changes in the field of activity of the Carnegie Corporation during his nineteen years of office, in which he emphasizes the possibility of a foundation adjusting itself to meet sharply changing conditions if its house is in order financially and otherwise. Its trustees should not only represent financial judgment and experience but also lay opinion, and they should possess a true understanding of the importance of education in a civilized society. He also stresses the value of a closely knit programme in each field of activity, and the necessity of being prepared to withdraw from a field in which the law of diminishing returns begins to operate, and finally the importance of timing, of endeavouring to have the idea, the man and the setting in perfect conjunction: the idea, vital and timely; the scholar or executive at the peak of his powers; and the organization at flood tide.

\section{Rodent Pests in War-time}

Mr. A. D. Mrdoleton has given some useful information for the control of the rabbit population of Great Britain (J.Min. Agric., 48, No. 2). $\mathrm{He}$ believes the best prospects for success depend upon better co-ordination of effort with county pest officers instead of individual efforts at control without cooperative schemes, but that it is unreasonable to commercialize it and to expect a profit from rabbit control. However, the high price of rabbits and the 